\title{
The Fontan outcomes network: first steps towards building a lifespan registry for individuals with Fontan circulation in the United States - CORRIGENDUM
}

\section{Corrigendum}

Cite this article: Alsaied T, Allen KY, Anderson JB, Anixt JS, Brown DW, Cetta F, Cordina R, D'udekem Y, Didier M, Ginde S, Di Maria MV, Eversole M, Goldberg D, Goldstein BH, Hoffmann E, Kovacs AH, Lannon C, Lihn S, Lubert AM, Marino BS, Mullen E, Pickles D, Rathod RH, Rychik J, Tweddell JS, Wooton S, Wright G, Younoszai A, Glenn T, Wilmoth A, and Schumacher K (2020) The Fontan outcomes network: first steps towards building a lifespan registry for individuals with Fontan circulation in the United States - CORRIGENDUM. Cardiology in the Young 30: 1381. doi: 10.1017/

S1047951120002462

First published online: 30 July 2020
Tarek Alsaied, Kiona Y. Allen, Jeffrey B. Anderson, Julia S. Anixt, David W. Brown, Frank Cetta, Rachael Cordina, Yves D'udekem, Meghan Didier, Salil Ginde, Michael V. Di Maria, Michelle Eversole, David Goldberg, Bryan H. Goldstein, Erin Hoffmann, Adrienne H. Kovacs, Carole Lannon, Stacey Lihn, Adam M. Lubert, Bradley S. Marino, Emily Mullen, Diane Pickles, Rahul H. Rathod, Jack Rychik, James S. Tweddell, Sharyl Wooton, Gail Wright, Adel Younoszai, Tom Glenn, Alicia Wilmoth and Kurt Schumacher

DOI: https://doi.org/10.1017/S1047951120001869 Published online by Cambridge University Press: 08 July 2020

The authors apologise that upon publication of this article two authors were missed off and placed in the acknowledgements section instead. The online version of this article has been updated to list the authors correctly.

Tarek Alsaied, Kiona Y. Allen, Jeffrey B. Anderson, Julia S. Anixt, David W. Brown, Frank Cetta, Rachael Cordina, Yves D’udekem, Meghan Didier, Salil Ginde, Michael V. Di Maria, Michelle Eversole, David Goldberg, Bryan H. Goldstein, Erin Hoffmann, Adrienne H. Kovacs, Carole Lannon, Stacey Lihn, Adam M. Lubert, Bradley S. Marino, Emily Mullen, Diane Pickles, Rahul H. Rathod, Jack Rychik, James S. Tweddell, Sharyl Wooton, Gail Wright, Adel Younoszai, Tom Glenn, Alicia Wilmoth and Kurt Schumacher

\section{Reference}

Alsaied, T., Allen, K., Anderson, J., Anixt, J., Brown, D., Cetta, F., ... Schumacher, K. (2020). The Fontan outcomes network: First steps towards building a lifespan registry for individuals with Fontan circulation in the United States. Cardiology in the Young, 1-6. doi: 10.1017/S1047951120001869 